\title{
BIMBINGAN KONSELING KARIR UNTUK ANGGOTA KARANG TARUNA KABUPATEN MAJALENGKA
}

\author{
Yucky Putri Erdiyanti, Titih Nurhaipah \\ Universitas Majalengka \\ yuckyerdiyanti@unma.ac.id
}

\begin{abstract}
The purpose of serving society is to provide information and direction about the career options of youth group members. Public service is carried out in the Majalengka Regency Social Services Chamber. The material presented in this briefing is about career counseling for young members. The number of participants in the seminar is 91. Career guidance service guidance helps the community, especially young men and women, in their careers or working life. Career guidance counseling is a conceptual basic capital that can be used as a tool to facilitate the sustainability of a career or job according to the competencies of the society. Young people who are members of the youth organization play an important role in advancing the region they live in. The importance of the role of counseling in providing career guidance for young people is appropriate for the situation of society or young women with a desire and desire to progress in a career or job. Counselors should be professional in providing career guidance counseling for community-based youth activities at Majalengka Regency. The results of this event are dedicated diaries and publicist in print media.
\end{abstract}

Keywords: counseling guidance; career; youth organization

\begin{abstract}
Abstrak
Tujuan pengabdian kepada masyarakat ini adalah untuk memberikan pengetahunan dan arahan mengenai pilihan karir anggota karang taruna. Pengabdian kepada masyarakat ini dilaksanakan di Aula Dinas Sosial Kabupaten Majalengka. Materi yang disampaikan pada pengarahan ini adalah tentang bimbingan konseling karir bagi anggota karang taruna. Jumlah peserta seminar sebanyak 91 peserta. Orientasi layanan bimbingan konseling karir membantu masyarakat khususnya pemuda dan pemudi dalam kehidupan berkarir atau bekerja. Bimbingan konseling karir merupakan modal landasan konseptual yang dapat dijadikan mediator guna memfasilitasi keberlangsungan masyarakat dalam berkarir atau bekerja sesuai dengan kompetensi yang dimilikinya. Pemuda pemudi yang tergabung dalam kegiatan karang taruna memiliki peran penting dalam memajukan daerah tempat tinggalnya. Pentingnya peran konselor dalam memberikan bimbingan konseling karir berlandaskan kegiatan karang taruna, disesuaikam dengan keadaan masyarakat atau pemuda pemudi yang memiliki cita- cita dan keinginan untuk maju dalam berkarir ataupun bekerja. Konselor harus mampu secara professional dalam memberikan bimbingan konseling karir kepada masyarakat berlandaskan kegiatan karang taruna di Kabupaten Majalengka. Luaran dari kegiatan ini berupa jurnal pengabdian dan publis di media cetak.
\end{abstract}

Kata Kunci: bimbingan dan konseling; karir; karang taruna

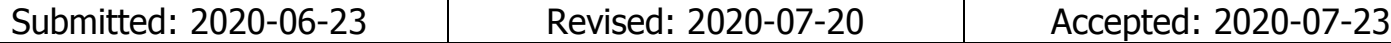

\section{Pendahuluan}

Bimbingan dan konseling merupakan bagian integral dari sistem pendidikan nasional. Pelayanan bimbingan dan konseling pada dasarnya membantu dan menyokong tercapainya tujuan pendidikan nasional, yaitu mewujudkan individu yang utuh, yang mampu memanfaatkan potensi yang dimiliki secara optimal untuk mengatasi permasalahan yang dihadapi. Sukardi (2008:20) mengemukakan bimbingan 
karir adalah suatu proses untuk membantu pribadi untuk mengembangkan penerimaan kesatuan dan gambaran diri serta peranannya dalam dua kerja.

Mensosialisasikan bimbingan konseling karir kepada masyarakat Majalengka, khususnya pada kalangan pemuda pemudi yaitu karang taruna Kabupaten Majalengka dengan memperkenalkan apa itu bimbingan konseling karir, tujuan serta manfaatnya. Pada kegiatan karang taruna di Kabupaten Majalengka, saya ikut serta dalam mengikuti perkembangan dan kegiatan yang diadakan termasuk perkumpulan atau musyawarah pada setiap bulannya. Kegiatannya termasuk mengadakan lombalomba, seperti sepak bola, permainan serta pertunjukan musik di lapangan direncakan dan dicanangkan oleh para pemuda pemudi yang bergerak dan berorganisasi di karang taruna Majalengka. Layanan informasi karir yang saya kembangkan pada dasarnya merupakan layanan yang memberikan data atau fakta kepada pemuda pemudi tentang dunia pekerjaan atau karir. Informasi karir mencakup semua data mengenai jenis - jenis pekerjaan yang ada di masyarakat, mengenai posisi dalam lingkup suatu jabatan, mengenai persyaratan tahap dan jenis pendidikan, mengenai sistem klasifikasi jabatan, dan mengenai prospek masa depan berkaitan dengan kebutuhan masyarakat akan jenis pekerjaan tertentu.

Sebagian besar orang menganggap bekerja dan memiliki karir adalah hal yang penting dan merupakan kebutuhan yang harus dilakukan. Karena tanpa bekerja kita tidak dapat memenuhi kebutuhan - kebutuhan hidup kita. Bagi pemuda pemudi yang ikut dalam kegiatan karang taruna dapat mengembangkan minat dan bakatnya sesuai degnan bidang yang mereka tekuni, karang taruna menciptakan pemuda dan pemudi yang mempunyai karakter serta kemauan besar untuk berkarir demi memajukan daerahnya tersebut dan membawa energi positif bagi pribadi, keluarga, masyarakat dan bangsa

Baru baru ini Majalengka masuk nominasi 4 besar kabupaten kreatif se indonesia dan sebagai satu satu nya perwakilan dari jawa barat, selain itu Majalengka memiliki bandarainternasional Jawa barat yang ada dikecamatan Kertajati, yang sekarang menjadi icon. Oleh karena itu pemuda pemudi di kabupaten majalengka harus memanfaatkan peluang pekerjaan yang ada di Kabupaten Majalengka.

Melalui wadah kepemudaan karang taruna, diharapkan pemuda pemudi di kabupaten majalengka bisa mendapatkan peluang untuk memanfaatkan potensi yang ada di kabupaten Majalengka. Oleh sebab itu para pemuda dan pemudi di Majalengka banyak yang mengikuti kegiatan karang taruna serta mengembangkan minat bakatnya masing-masing didaerahnya tersebut. Kemajuan daerah tersebut sangat berpengaruh terhadap kegiatan karang taruna para pemuda pemudi yang sangat mendukung perkembangan masyarakat yang utuh dan bertoleransi. Seperti pada layanan bimbingan konseling karir penting diberikan bagi remaja, sebagai salah satu sarana meningkatkan kesejahteraan remaja dengan memiliki peluang untuk mencapai masa depan yang menjanjikan. Santrock (2007:15) mengingatkan bahwa "masa depan anak muda merupakan masa depan masyarakat kita. 
Remaja yang belum mengembangkan potensinya secara utuh, yang hanya memberikan kontribusi yang kecil, yang tidak berperan sebagai orang dewasa yang produktif, akan merugikan masa depan masyarakat kita.

\section{Metode}

Kegiatan ini dilaksanakan sebagai wujud dari Tridharma perguruan tinggi dosen Universitas Majalengka, Target dan sasaran pengabdian pada masyarakat ini secara umum adalah anggota karang taruana se Kabupaten Majalengka. Rencana jangka panjang ke depan pelatihan ini dapat berguna untuk kemajuan anggota tarang taruna di Kabupaten Majalengka, dan diharapkan dapat terciptanya jenjang karir yang tepat bagi anggota karang taruna di Kabupaten Majalengka . Studi Analisis Kebutuhan, yakni mengidentifikasi secara keilmuan dalam bimbingan konseling karir. Pelaksanaan, yakni bimbingan konseling karir secara umum pada satu tempat yang diawali dengan penyelenggaraan pelatihan secara keilmuan bimbingan konseling karir, dijadwal berikutnya mulai mentreadmen anggota karang taruna dengan bimbingan konseling karir. Evaluasi, yakni kemajuan pemahaman karir setelah treadmen dilakukan, yakni program bimbingan konseling karir

Kegiatan dalam hal ini sebagai kerangka pemecahan masalah maka dilakukan dalam bentuk bimbingan dan konseling dengan beberapa tahapan pelaksanaan kegiatan diantaranya:

1. Persiapan

a. Melakukan kontak awal dengan pihak karang taruna kabupaten Majalengka untuk menelusuri kemungkinan pelaksanaan kegiatan di dinas sosial kabuapeten Majalengka dan prosedur yang harus dijalankan berkaitan dengan pelaksanaan kegiatan. Serta menentukan pertemuan awal untuk membahas pelaksanaan kegiatan

b. Tahap obervasi berupa survei awal, melakukan pertemuan secara langsung dengan ketua karang taruna kabupaten Majalengka. Menelusuri lebih dalam mengenai fenomena - fenomena pilihan karir anggota karang taruan kabupaten Majalengka untuk muatan materi bimbingan konseling karir yang akan disampaikan.

c. Membahas treadmen konseling karir apa yang tepat untuk anggota karang taruna kabupaten Majalengka ini.

2. Pelatihan

Kegiatan pelatihan dilakukan secara webinar dengan cara komperense online dengan peserta, dilanjutkan dengan diskusi. Bimbingan ini dibagi ke dalam beberapa materi, yaitu:

a. Pemahaman dasar mengenai bimbingan konseling karir.

b. Pemaparan materi Informasi tentang dunia kerja, hubungan industrial, dan layanan perkembangan belajar.

c. Materi Substansi informasi dunia kerja, meliputi antara lain lapangan kerja, jenis dan persyaratan jabatan, prospek dunia kerja, budaya kerja.

d. Substansi hubungan industrial, meliputi hubungan kerja, sarana hubungan industrial, dan masalah khusus ketenagakerjaan. 


\section{Hasil dan Pembahasan}

Pada kegiatan karang taruna di Kabupaten Majalengka, saya ikut serta dalam mengikuti perkembangan dan kegiatan yang diadakan termasuk perkumpulan atau musyawarah pada setiap malam Minggu. Kegiatannya termasuk mengadakan lombalomba, seperti sepak bola, permainan serta pertunjukan musik di lapangan GGM Kabupaten Majalengka, itu semua direncakan dan dicanangkan oleh para pemuda pemudi yang bergerak dan berorganisasi di karang taruna Kabupaten Majalengka. Sukardi (2008:20) mengemukakan bimbingan karir adalah suatu proses untuk membantu pribadi untuk mengembangkan penerimaan kesatuan dan gambaran diri serta peranannya dalam dua kerja. Dapat diartikan bahwa bimbingan konseling karir sesungguhnya tidak hanya berlangsung selama anak didik duduk dalam bangku sekolah, tetapi juga berlangsung dalam pelaksanaan pekerjaan, jabatan atau karir itu sendiri yang tidak dapat dipisahkan dari aspek kehidupan manusia yang selalu mengalami perubahan, tantangan, pembaharuan, serta peningkatan secara kontinu sebagaimana yang dialami oleh manusia itu sendiri dalam hidup dan kehidupannya.

1. Pokok - pokok pelayanan bimbingan konseling karir di masyarakat yang saya kembangkan pada organisasi karang taruna Kabupaten Majalengka Jawa Barat

Bidang ini dapat dirinci menjadi pokok - pokok sebagai berikut:

a. Pemantapan pemahaman diri berkenaan dengan kecenderungan karir yang hendak dikembangkan.

b. Pemantapan orientasi dan informasi karir pada umumnya, khususnya karir yang hendak dikembangkan.

c. Orientasi dan informasi terhadap dunia kerja dan usaha memperoleh penghasilan untuk memenuhi kebutuhan hidup.

d. Orientasi dan informasi terhadap pendidikan yang lebih tinggi, khususnya sesuai dengan karir yang hendak dikembangkan.

2. Syarat - syarat dilaksanakan program bimbingan karir

Bimbingan karir dimasukkan ke dalam kerangka umum pendidikan karir, dimana bimbingan konseling karir di masyarakat Kabupaten Majalengka akan berfungsi dalam perkembangan karir para pemuda pemudi. Untuk itu program bimbingan konseling karir di masyarakat Kabupaten Majalengka meliputi:

a. Terpusat pada kegiatan pemuda pemudi, yang mengandung tuntutan memberikan serangkaian pengalaman yang dibutuhkan, yang mengandung tuntutan memberikan serangkaian pengalaman yang dibutuhkan untuk meningkatkan perkembangan karir mereka.

b. Berorientasi pada lingkungan sosial, ekonomi, dan budaya yang mengelilingi dalam masyarakat, dengan mengindahkan bahwa lingkungan itu akan mengalami berbagai perubahan yang mempunyai dampak terhadap perkembangan karir orang muda.

\section{Cakupan materi bimbingan konseling karir}


Program bimbingan karir disusun berdasarkan struktur program bimbingan dan konseling serta perkembangan karir. Adapun materi bimbingan karir menurut Salahudin (2010:119) mencakup:

a. Informasi tentang dunia kerja, hubungan industrial, dan layanan perkembangan belajar.

b. Substansi informasi dunia kerja, meliputi antara lain lapangan kerja, jenis dan persyaratan jabatan, prospek dunia kerja, budaya kerja.

c. Substansi hubungan industrial, meliputi hubungan kerja, sarana hubungan industrial, dan masalah khusus ketenagakerjaan.

d. Substansi layanan perkembangan belajar, meliputi antara lain kesulitan belajar, minat, dan bakat, masalah sosial, dan masalah pribadi.

4. Tujuan bimbingan dan konseling karir di masyarakat

Menurut Salahudin (2010:116) secara umum, tujuan bimbingan dan konseling karir di masyarakat adalah sebagai berikut:

a. Memiliki pemahaman diri (kemampuan, minat, dan kepribadian) yang terkait dengan pekerjaan.

b. Memiliki pengetahuan mengenai dunia kerja dan informasi karir yang menunjang kematangan kompetensi kerja.

c. Memahami relevansi kompetensi belajar (kemampuan menguasai pelajaran) dengan persyaratan keahlian atau keterampilan bidang pekerjaan yang menjadi cita - cita karirnya di masa depan.

d. Memiliki kemampuan untuk membentuk identitas karir, dengan cara mengenali ciri - ciri pekerjaan, kemampuan (persyaratan) yang dituntut, lingkungan sosiopsikologis pekerjaan, prospek kerja, dan kesejahteraan kerja.

Tujuan remaja dalam mengikuti kegiatan karang taruna di Kabupaten Majalengka ini adalah mencapai sesuatu yang bersangkutan dengan masa depan, yaitu pekerjaan atau karir serta belajar dalam berorganisasi dalam masyarakat. Usaha bimbingan konseling karir di masyarakat Kotagede untuk mempersiapkan pemuda pemudi dalam pengambilan keputusan karir antara lain berupa pemberian informasi sehubungan dengan pengetahuan, keterampilan, sikap serta nilai, yang semuanya diperlukan dalam menekuni karirnya dalam kegiatan karang taruna di Kabupaten Majalengka.

Bimbingan konseling karir sebagai "kombinasi dari berbagai aktifitas dan pengalaman dimana melalui berbagai aktifitas dan pengalaman tersebut individu individu memperpersiapkan diri mereka untuk bekerja (baik yang dibayar maupun tidak) selama hidup mereka.

Adapun program karang taruna kabupaten Majalengka Program umum adalah program kerja Karang Taruna yang dilaksanakan secara umum antara lain meliputi :

Penyelenggaraan kegiatan rapat pleno pengurus dan rapat koordinasi, Penyelenggaraan sensus anggota dalam rangka validasi data pengurus Karang Taruna, Unit Karang Taruna dan hubungan Karang Taruna, Konsolidasi dan koordinasi dengan pemerintah dalam upaya mencari peluang dan terobosan program kerja yang dapat dilaksanakan bersama dengan Karang Taruna, melaksanakan kegiatan Bulan Bakti Karang Taruna dan Penyelenggaraan operasional kesekretariatan Karang Taruna dalam upaya menjadikan sekretariat sebagai media informasi, komunikasi yang strategis bagi pemberdayaan Karang Taruna. 
Mekanisme kerja (langkah) guna melaksanakan tahapan tersebut ditempuh melalui pembicaraan dan pembahasan bersama dalam pertemuan atau rapat pengurus. Rapat setidaknya dapat merumuskan dan menetapkan antara lain hal-hal sebagai berikut :Kegiatan apa yang akan dikerjakan, Siapa yang mengkoordinasikan dan melaksanakan kegiatan tersebut, Dukungan dana yang diperlukan dan bagaimana memperolehnya, Siapa saja dan pihak mana saja yang perlu dihubungi, Pelaksanaannya bagaimana, Dan lain-lain yang perlu diputuskan dalam rapat. Pertemuan kembali untuk mengetahui perkembangan pelaksanaan, baik hasil, faktor pendukung dan permasalahan yang dihadapi dalam rangka menetapkan langkah-langkah berikutnya.

Program Bidang-Bidang

a. Bidang Organisasi meliputi revitalisasi pengurus Karang Taruna, Pembinaan Organisasi, Pendataan potensi anggota Karang Taruna

b. Bidang Pendidikan dan Pelatihan meliputi Pelatihan Manajemen Organisasi Karang Taruna, Penyelenggaraan diklat/kursus keterampilan kerja, Pengiriman pelatihan anggota Karang Taruna tingkat Pusat dan Provinsi, Memfasilitasi pendidikan bagi siswa tidak mampu, Memberikan Fasilitas Siswa Yang berprestasi, Memberikan kemudahan Bagi pengurus dan Anggota Karang Taruna Untuk mendapatkan pendidikan. Bidang pendidikan juga menyediakan berbagai macam pelatihan Ketrampilan Komputer, dia antaranya Menjahit Dan Tata Busana, Roda Dua dan empat, Tata Boga, Kerajinan dan Mengadakan penyuluhan Narkoba dan Hukum

c. Bidang Kemitraan, Kerja Sama Dan Tenaga Kerja di antaranya Pembentukan Taruna Tani dan Koperasi Karang Taruna, Penyelenggaraan kerja sama pembukaan usaha dengan instansi dan perusahan, Membuat Usaha Bengkel Las bekerja sama pihak ketiga, Membuat pangkalan Bahan Bakar Minyak (BBM) Dan Elpiji, Membuka usaha Usaha : Peternakan, Pertanian, Perkebunan, Perikanan

d. Bidang Usaha Kesejahteraan Sosial yaitu Mengupayakan kerja sama dengan pihak kesehatan dalam usaha Sosialisasi Kesehatan Reproduksi Remaja, Kerja sama program siaga ibu hamil, Penanganan masalah sosial, Menyelenggarakan Sunatan Massal, Melaksanakan kegiatan yang dibutuhkan masyarakat, Menjalin kerja sama dengan pengusaha-pengusaha lokal.

e. Bidang Pembinaan Kerohanian dan Pembinaan Mental di antaranya mengadakan pengajian rutin dan ceramah keagamaan, Pembentukan Pengajian pemuda Karang Taruna, Mengadakan peringatan Hari-hari Besar Islam, Menyemarakkan Bulan Suci Ramadhan, Turut serta dalam Pembentukan dan Atau Pengambangan Taman Pendidkan Seni Al-Qur'an (TPS) Pemuda Karang Taruna.

f. Bidang Lingkungan Hidup di antaranya menjalin kerja sama dengan BPLH dan Instansi terkait dalam menjaga dan mengadakan pelestarian lingkungan, Mengadakan program penerangan disepanjang jalan protokol desa, Penyelenggaraan Penghijauan dan pembenihan, Pemanfaatan lahan kosong sekitar rumah, Melaksanakan Kebersihan Lingkungan, Mengadakan perlombaan kebersihan, Melaksanakan Jum'at Bersih

g. Bidang Olah Raga, Seni Budaya Dan Pariwisata diantaranya Pengembangan olah raga secara terpadu, berkala dan berkelanjutan, Pembentukan Club Olahraga seperti Sepak Bola, Volly Ball, Bulu Tangkis, Tennis Meja Futsal. Penyelenggaraan agenda 
rutin event olah raga dan seni budaya, Meng"Olah Raga"kan masyarakat Memasyarakatkan Olah raga dan membimbing bagi Anak-anak dan pemuda yang memiliki bakat dan minat Olahraga, Mengirim Utusan Club Olahraga pada turnamen dan even Olahraga, Pembentukan taruna budaya, Pengembangan seni budaya dan kerajinan tradisional, Menggali dan mengembangkan potensi wisata, Membantu promosi wisata dan potensi lokal pada event karang taruna, Mengadakan karya wisata, Pembentukan Group Pendidkan Seni Pemuda Karang Taruna, Menyalurkan Bakat bagi yang berpotensi dalam seni tarik suara, Mengaktifkan Sanggar Adat dan Budaya.

h. Bidang Hukum Dan HAM, bekerja sama dengan kepolisian menyelenggarakan kegiatan kadarkum, Membantu advokasi hukum bagi warga Karang Taruna yang bersangkutan dengan hukum dan Sosialisasi HAM.

i. Bidang Pemberdayaan Masyarakat Dan Perempuan. Partisipasi bagi program rumah tidak layak huni, Penyelenggaraan usaha pemberdayaan masyarakat dan Peningkatan peran gender pada posisi strategis di Karang Taruna

j. Bidang Humas. Menjaga Hubungan harmonis Karang Taruna dengan Masyarakat, Meyampaikan program- program yang dilaksanakan Karang Taruna Kepada Masyarakat dan Membuat Papan Informasi Karang Taruna Dan Pemerintahan

Untuk menyesuaikan program karang taruna Kabupaten Majalengka saya mengambil point B yaitu Bidang Pendidikan dan Pelatihan yang salah satu program nya adalah kepelatihan bimbingan karir untuk anggota karang taruna. Kegiatan yang kami lakukan adalah mengadakan webinar dengan judul Bimbingan Konseling Karir Untuk Pemuda di Era Adaptasi Kebiasaan Baru yang kami laksanakan pada hari sabtu 20 Juni 2020, menghadirkan 91 peserta.

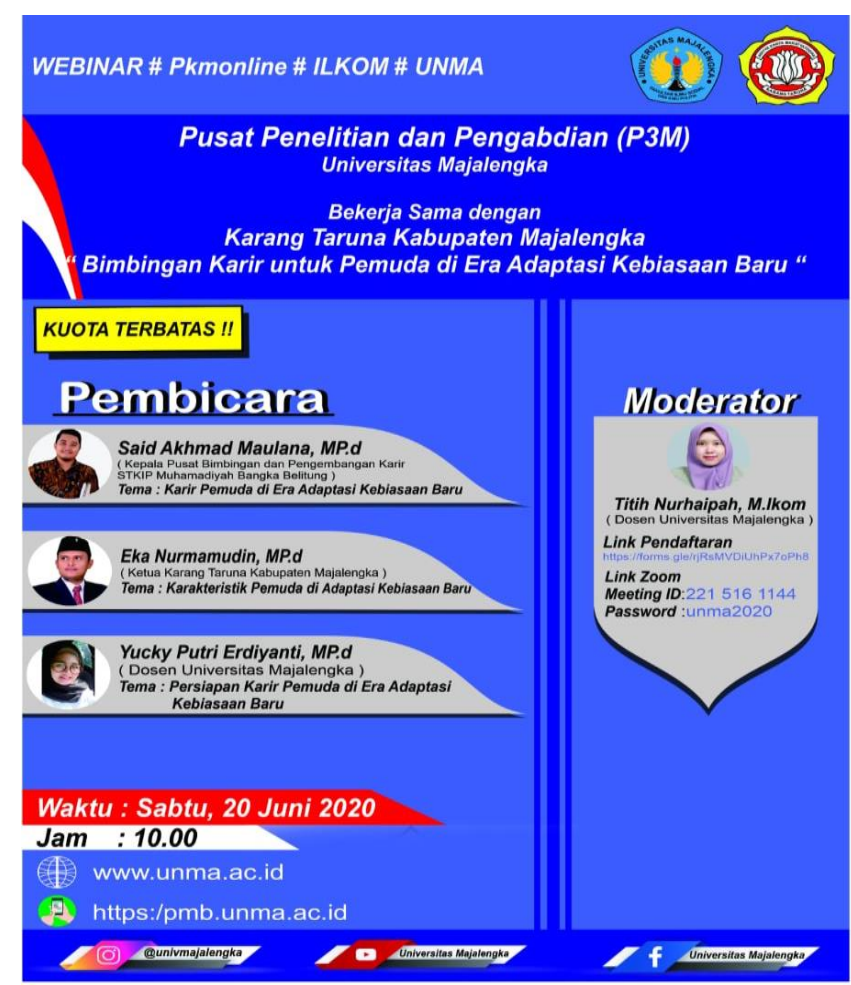

Gambar 1. Poster Webinar 


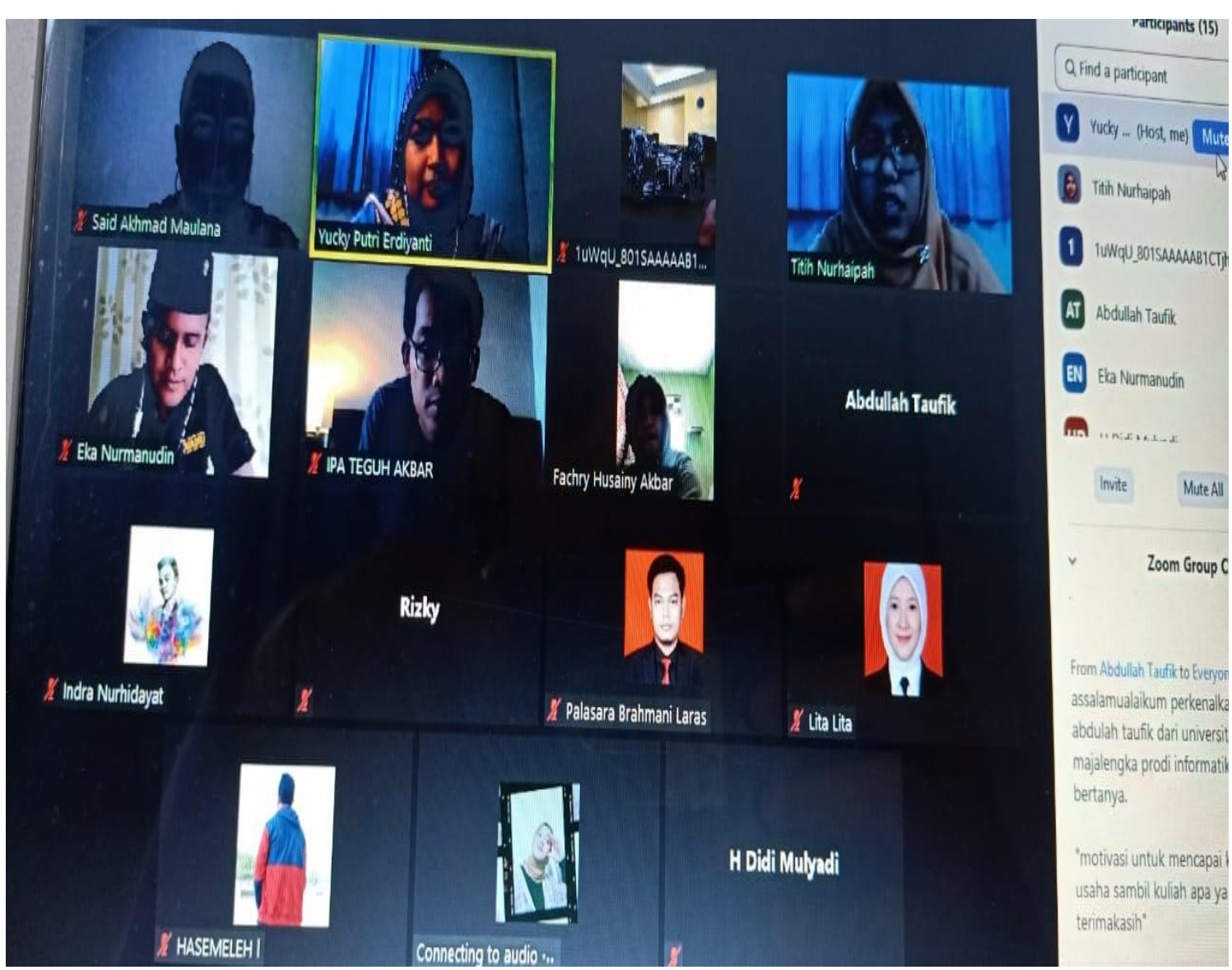

Gambar 2. Pelaksanaan Webinar

Materi yang kami angkat dalam webinar tersebut adalah Perencanaan Karir Agar Masa Depan Sukses yang menjelaskan tentang karir masa depan pemuda yang meliputi 10 perencanaan karir yang harus di rencanakan agar karir sukses. Sukses dalam karir identik dengan kesejahteraan. Dibutuhkan pengetahuan dan perencanaan karir yang tepat di masa depan agar kita bisa meraih impian seperti yang kita inginkan. Hal ini merupakan sesuatu yang penting bagi karyawan. Dalam dunia kerja, ada perusahaan yang dengan senang hati memikirkan karier karyawannya dan ada pula perusahaan yang hanya menguras tenaga karyawan tanpa memikirkan masa depan mereka.

Masa depan adalah gambaran dari apa yang kita rencanakan dan akan lakukan nantinya. Oleh karena itu jangan berharap masa depan cerah jika saat ini tidak melakukan perencanaan yang baik. Berikut ini 10 langkah praktis yang bisa membantu menyusun masa depan yang cerah:

1. Menyusun Visi Mulai Sekarang yang Bisa Berawal dari Impian

2. Mulai Mengenali Diri, Jangan Fokus pada Kelemahan, Pacu terus Kekuatan

3. Review Pencapaian Masa Lalu, Pacu Bidang yang Sudah Berhasil, Jangan Fokus pada Kegagalan

4. Fokus dan Tingkatkan terus Keterampilan yang Dikuasai

5. Ikuti Passion karena Passion akan Menunjang Keterampilan sehingga Bisa Menjadi Profesional dalam Bekerja 
6. Cermat Membaca Tren dan Peluang Karir di Masa Depan

7. Membuat Career Path yang Terukur dengan Metode "SMART"

8. Jalankan Rencana Karir yang sudah Dibuat dengan Disiplin dan Bertanggung Jawab

9. Demi Menunjang Tujuan yang Ingin Diraih, Tingkatkan Terus Keterampilan dan Level Pendidikan

10. Lakukan Evaluasi Perencanaan Karir Secara Berkala, Bisa Triwulan, Semester atau Tahunan.

Bersadarkan hasil pengolahan data prestes dan postes dapat disimpulkan bahwa bimbingan dan konseling karir dapat meningkatkan pemahaman pemuda tentang pemilihan karir masa depan nya. Berdasarkan hasil pengolahan didapat bahwa $50 \%$ peserta bimbingan menyatakan bahwa bimbingan karir untuk pemuda sangat penting, dan $50 \%$ menyatakan penting. Peserta menyatakan bahwa melalui kegiatan pelatihan ini menjadi bertambah pemahaman tentang bimbingan dan konseling karir, yaitu $45 \%$ peserta sangat paham dan sisanya $55 \%$ peserta paham.

\section{Kesimpulan}

Pelayanan bimbingan konseling karir di masyarakat Kabupaten Majalengka khususnya karang taruna diharapkan bermanfaat bagi pemuda pemudi yang akan mengembangkan minat dan bakatnya dalam kegiatan karang taruna yang sangat mendukung dalam kegiatan yang positif dalam masyarakat

\section{Daftar Pustaka}

Prayitno \& Amti, Erman. 2004. Dasar - Dasar Bimbingan Dan Konseling. Jakarta: Rineka Cipta.

Program Karang taruna Kabupaten Majalengka 2018-2022

Salahudin, Anas. 2010. Bimbingan \& Konseling. Bandung: CV. Pustaka Setia. Santrock, John W. 2007. Remaja. Edisi Kesebelas. Jakarta: rlangga.

Sukardi, Dewa Ketut. 2008. Bimbingan Karir di Sekolah-sekolah. Jakarta: Ghalia Indonesia. 